\title{
Consequence of chromium-tainted soil on physical and biochemical responses of Vigna radiata L.
}

\author{
Bibhu Prasad Rath ${ }^{1}$, Sujata Hota ${ }^{1}$, Subhra Subhadarshini ${ }^{1}$, Debasis Dash ${ }^{1}$, Prabhu Kaibalya Das ${ }^{2 *}$ \\ ${ }^{1}$ Department of Botany, Orissa University of Agriculture and Technology, Bhubaneswar, Odisha, India, ${ }^{2}$ Department of Zoology, Khallikote University, \\ Berhampur, Odisha, India
}

\section{ARTICLE INFO}

Article history:

Received on: March 23, 2018

Accepted on: May 07, 2018

Available online: January 20, 2019

Key words:

Leguminous,

Chromium,

Physical responses,

Biochemical responses,

Contaminated soil

\section{ABSTRACT}

Mung bean (Vigna radiata L.) is one of the important leguminous plants of India, with shorter growing season. In this work, the intention was to correlate the effects of chromium on physical and biochemical responses of $V$. radiata $\mathrm{L}$. Mung bean seeds were germinated and grown under controlled treatment, with different concentrations of waste soil mixed with garden soil. Physical parameters such as shoot length, root length, and fresh weight were found highest in control soil and $25 \%$ of contaminated soil, whereas $50 \%$ and pure contaminated soil showed poor growth stage and poor quality physical parameters. Biochemical parameters such as total chlorophyll content, protein content, and starch content were found highest in control soil and $25 \%$ contaminated soil, but these parameters were found to be less in $50 \%$ and pure contaminated soil. It was observed that physical and chemical parameters were declining with increasing chromium contamination.

\section{INTRODUCTION}

Heavy metals are major pollutants as they influence multiple organ damages even at low levels of exposure. Heavy metal pollution is the result of anthropogenic activities such as mining, energy and fuel production, power transmission, intensive agricultural practices, sludge and industrial effluent dumping, and military operations $[1,2]$. Metals such as aluminum, arsenic, cadmium, cobalt, chromium, copper, lead, manganese, mercury, nickel, selenium, and zinc have been considered as the major environmental pollutants, and their phytotoxicity has already been studied [1]. Raised concentrations of both essential and non-essential heavy metals in the soil and water can lead to toxicity symptoms and growth inhibition in most plants [3-5]. Absorption, translocation, and accumulation of heavy metal ions of $\mathrm{Hg}, \mathrm{Pb}, \mathrm{Cr}$, and $\mathrm{Cd}$ by plants, reduce productivity of the species and cause severe health hazards through the food chain to other life forms [6-8].

\subsection{Effect of Chromium Toxicity in Plants}

$\mathrm{Cr}$ phytotoxicity can result in reticence of seed germination, degrade pigment status, nutrient balance, antioxidant enzymes, and prompt oxidative stress in plants [9]. $\mathrm{Cr}$ can change chloroplast and

*Corresponding Author:

Prabhu Kaibalya Das, At/P.O.; Arisandha, Nimapara, Puri, Berhampur - 752 106, Odisha, India. Phone: +91-8455960818. Email: dprabhukaibalya216@gmail.com membrane, ultrastructure [10,11]. In higher plants, heavy metals induce oxidative stress by generation of superoxide radical $\left(\mathrm{O}_{2}^{-}\right)$, hydrogen peroxide $\left(\mathrm{H}_{2} \mathrm{O}_{2}\right)$, hydroxyl radical $(\mathrm{OH})$, and singlet of oxygen $\left(\mathrm{O}_{2}\right)$ collectively termed as reactive oxygen species (ROS). ROS can rapidly attack all types of biomolecules such as nucleic acids, proteins, and amino acids, leading to irreparable metabolic dysfunction and cell death. ROS produced under stress is unfavorable to growth because these molecules cause steady lipid peroxidation, inactivation of antioxidant enzymes, and oxidative dehydroascorbic acid damage $[12,13]$. Therefore, induction of antioxidant enzymes including superoxide dismutase (SOD), catalase (CAT), and peroxidase (POD) is an important protective mechanism to minimize oxidative damage in plants. SOD is ubiquitous enzyme which plays a key role in cellular defense mechanism against ROS [14]. Its activity modifies the relative amount of $\mathrm{O}_{2}^{-}$and $\mathrm{H}_{2} \mathrm{O}_{2}$ by Haber-Weiss reactions and reduces the risk of $\mathrm{OH}$ radical formation which is highly reactive and may cause severe damage to membrane proteins and DNA [5,15]. CAT is less effective in eradicating $\mathrm{H}_{2} \mathrm{O}_{2}$ due to its low substrate affinity while the main response of tolerant plants to heavy metal is increase in SOD and POD activities [16,17]. $\mathrm{Cr}$ (III) is toxic to plants even at low concentration and reported to causes severe oxidative damage to plant cell. It affects growth, water balance, and pigment content and initiates lipid peroxidation causing oxidative damage to plants $[18,19]$. Cr (VI), on the other hand, is more phytotoxic than $\mathrm{Cr}$ (III) and retards growth, reduces the number of palisade and spongy parenchyma cells in leaves, and increases the number of vacuoles and electron dense material along the walls of xylem and phloem [20]. 


\section{MATERIALS AND METHODS}

\subsection{Study Area}

As per the statistics, Odisha accounts for about $98 \%$ of the total chromite (chromium ore) reserves of the country, of which about $97 \%$ occur in the Sukinda Valley, Sukinda is a town in Jaipur district, Odisha, India. Sukinda is situated in between longitude $20^{\circ} 58^{\prime} 0^{\prime \prime} \mathrm{N}$ and latitude $85^{\circ} 55^{\prime} 0^{\prime \prime} \mathrm{E}$. The area of study was Kaliapani, Sukinda, Odisha. Kaliapani is a small place in Sukinda according to its size, but it is a highly economically important place of India.

\subsection{Collection of Soil Sample}

The waste soil of the overburden was collected from Saruabil Chromite Mines, Kaliapani, Sukinda, Odisha. The waste soil was collected in gunny bags and kept under air in field condition for $48 \mathrm{~h}$ to decrease its moisture level. It was then powdered, sieved, and subjected to analysis for various important constituents.

The $\mathrm{pH}$ of the dark-colored soil of the study area was measured to be $7.10 \pm 0.03$ having electrical conductivity $46.33 \mu \mathrm{s} / \mathrm{ppm}$. It contains $5.433 \mathrm{mg}$ of chromium per $\mathrm{kg}$ of the waste soil as analyzed by atomic absorption technique. Potassium contents of the waste soil were $0.224 \mathrm{~kg} / \mathrm{ha}$, respectively.

\subsection{Preparation of Culture Pots}

The dried and powdered waste soil was used for the preparation of culture pots with garden soil to study the effect of the waste soil combination on Vigna radiata L. and also to compare the effect with control soil taken from garden on $V$. radiata $\mathrm{L}$. Three different concentrations of soil sample were taken in triplicate with comparison to control garden soil $(\mathrm{pH} 6.88 \pm 0.03)$ [Table 1]. The concentrations of waste soil in pots were as follows:

- $\quad$ Pot $1-100 \%$ waste soil ( $\mathrm{pH} 7.10 \pm 0.03$, EC $46.33 \mu \mathrm{s} / \mathrm{ppm})$

- Pot $2-50 \%$ waste soil with $50 \%$ control soil ( $\mathrm{pH} 6.85 \pm 0.03, \mathrm{EC}$ $44.16 \mu \mathrm{s} / \mathrm{ppm})$

- $\quad$ Pot $3-25 \%$ waste soil with $75 \%$ control soil ( $\mathrm{pH} 6.70 \pm 0.03$, EC $43.50 \mu \mathrm{s} / \mathrm{ppm})$

- $\quad$ Pot 4 - Control soil (100\% normal garden soil) $(\mathrm{pH} 6.88 \pm 0.03$, EC $46.20 \mu \mathrm{s} / \mathrm{ppm})$.

In each pot soil, sample was taken in a constant weight of $2 \mathrm{~kg}$, and combinations were prepared according to the concentration of the waste soil sample taken. Pot 1 was having $2 \mathrm{~kg}$ of $100 \%$ waste soil, pot 2 was having $1 \mathrm{~kg}$ of waste soil and $1 \mathrm{~kg}$ of control soil (total $2 \mathrm{~kg}$ ), pot 3 was having $500 \mathrm{~g}$ of waste soil and $1.5 \mathrm{~kg}$ of control garden soil (total $2 \mathrm{~kg}$ ), and pot 4 was having $2 \mathrm{~kg}$ control soil.

The pots were kept on roof and were watered equally. The soil water mixture was allowed to settle for 2 days. Seeds of $V$. radiata L. were sown in the pots containing varying contaminated waste soil combinations. The pots were arranged in triplicate and various parameters were observed on the $15^{\text {th }}$ day from seed germination and on the $30^{\text {th }}$ day from germination.

\subsection{Available Chromium (Cr)}

The available chromium of the soil samples after combination was determined by DTPA (Pentetic acid or diethylene triamine pentaacetic acid) extraction method. $10 \mathrm{~g}$ of each soil sample was dissolved in $20 \mathrm{ml}$ of DTPA solution. Then, it was shaken for $2 \mathrm{~h}$ and filtered using 42 number filter paper. Reading was taken using atomic absorption spectroscopy. The unit of available chromium was taken in $\mathrm{mg} / \mathrm{kg}$. The waste soil had $5.433 \mathrm{mg} / \mathrm{kg}$ of available chromium, whereas the combinations showed decrease in concentration of available chromium content varying from $2.016 \mathrm{mg} / \mathrm{kg}$ ( $50 \%$ waste soil $+50 \%$ control soil) and $1.725 \mathrm{mg} / \mathrm{kg}(25 \%$ waste soil $+75 \%$ control soil), respectively.

\subsection{Available Nitrogen (N)}

The available nitrogen of the soil samples after combination was determined by alkaline potassium permanganate method in Kel Plus automatic machine [21]. The waste soil had $25 \%$ of available nitrogen, whereas the combinations showed increase in the concentration of available nitrogen content varying from $75 \%$ (pot 2), 87.5\% (pot 3), and control was having $112.5 \%$ of nitrogen, respectively.

\subsection{Available Potassium (K)}

The available potassium of the soil samples after combination was determined by flame photometry. $7.709 \mathrm{~g}$ of ammonium acetate dissolved in $100 \mathrm{ml}$ of distilled water. Then, $5 \mathrm{~g}$ of each soil sample was dissolved in $25 \mathrm{ml}$ of ammonium acetate solution. Then, it was shaken and $\mathrm{pH}$ was maintained up to 7.0 and filtered. Reading was taken using flame photometer. The unit of available potassium was taken in $\mathrm{kg} / \mathrm{ha}$. The waste soil had $0.224 \mathrm{~kg} / \mathrm{ha}$ of available potassium, whereas the combinations showed increase in the concentration of available potassium content varying from $18.37 \mathrm{~kg} / \mathrm{ha}$ (pot 2), $40.21 \mathrm{~kg} / \mathrm{ha}$ (pot 3), and control was having $61.04 \mathrm{~kg} / \mathrm{ha}$.

\subsection{Seed Sowing}

Seeds are rinsed with water for 3-4 times. The seeds were sown in the pots at a rate of 6 ( $V$. radiata L.) seeds per pot.

\subsection{Shoot Length $(\mathrm{cm})$ and Root Length $(\mathrm{cm})$}

On the day of final count of the germination test, i.e., $15^{\text {th }}$ and $30^{\text {th }}$ days, $5 / 6$ normal seedlings were collected from each treatment and in each replication. The shoot length was measured from the base of primary leaf to the base of hypocotyl, and mean shoot length was expressed in centimeters.

$5 / 6$ seedlings used for shoot length measurement were also used for the root length measurement. It was measured from the tip of primary root to the base of hypocotyl, and mean root length was expressed in centimeters.

Table 1: Different soil parameters

\begin{tabular}{|c|c|c|c|c|c|}
\hline Treatment & pH & $\mathbf{E C}(\mu \mathbf{s} / \mathbf{p p m})$ & Available Cr. (mg/kg) & Available n (\%) & Available K (kg/ha) \\
\hline $100 \%$ waste soil - pot 1 & $7.10 \pm 0.03$ & 46.33 & 5.433 & 25 & 0.224 \\
\hline $50 \%$ waste soil $+50 \%$ control soil - pot 2 & $6.85 \pm 0.03$ & 44.16 & 2.016 & 75 & 18.370 \\
\hline $100 \%$ control (normal garden soil) - pot 4 & $6.88 \pm 0.03$ & 46.20 & Not detected & 112.5 & 61.040 \\
\hline
\end{tabular}




\subsection{Sampling Procedure}

\subsubsection{Extraction and estimation of chlorophyll}

The leaves were analyzed for total chlorophyll content by homogenizing $500 \mathrm{mg}$ of leaves in $80 \%$ acetone, and the extract was centrifuged, and the supernatant was analyzed for chlorophyll content in a spectrophotometer. The chlorophyll content was calculated as described by Arnon's method [22].

\subsubsection{Extraction and estimation of protein}

Extracted leaf samples were precipitated with 50\% trichloroacetic acid and then centrifuged at 10,000 rpm for $15 \mathrm{~min}$. Residue was dissolved in $1 \mathrm{~N} \mathrm{NaOH}$ to it $5 \mathrm{ml}$ of reagent mix $\left(2 \% \mathrm{Na}_{2} \mathrm{CO}_{3}\right.$ in 0.1 $\mathrm{NaOH}, 0.5 \% \mathrm{CuSO}_{4}$ in $1 \%$ Rochelle's salt), $0.5 \mathrm{ml}$ of Folin's reagent added. Incubation was done for $30 \mathrm{~min}$ and then OD was taken at $650 \mathrm{~nm}$ [23].

\subsubsection{Starch estimation}

The leaves were analyzed for starch content by Anthrone reagent method as described by Clegg. Then, it was analyzed for starch content in a spectrophotometer [24].

\section{RESULTS AND DISCUSSION}

In heavy metal contamination, heavy metals are dispersed with soil particles from early contaminated region by air and water. When these particles are settled, heavy metals may scatter into the adjoining areas.

\subsection{Effect of Chromium-contaminated Soil on Quality Parameters of $V$. radiata $L$.}

In Table 2, it was observed that the shoot length [Figure 1] and root length [Figure 2] (as per the $15^{\text {th }}$ day of germination) were highest in the control treatment followed by $25 \%$ and $50 \%$ contaminated soil. Further, lowest was recorded in the $100 \%$ contaminated soil.

However, the results were changed in the $30^{\text {th }}$ day of germination. The shoot length [Figure 1] and root length [Figure 2] were highest recorded in $25 \%$ contaminated soil than the control soil. Then, it was followed by $50 \%$, and finally, the lowest was recorded in $100 \%$ contaminated soil [Table 3].

After the $15^{\text {th }}$ day of germination, the fresh weight [Figure 3] was found highest in the treatment of control soil followed by $25 \%$ contaminated soil, followed by $50 \%$ contaminated soil. Further, lowest fresh weight was recorded in $100 \%$ contaminated soil [Table 2].

However, after the $30^{\text {th }}$ day of germination, the fresh weight [Figure 3] was found highest in $25 \%$ contaminated soil, followed by control soil, $50 \%$ contaminated soil and was lowest in $100 \%$ waste soil [Table 3]. Decreased root growth and seedling development are persuaded by chromium phytotoxicity [25].

\subsection{Effect of Chromium-contaminated Soil on Total Chlorophyll Content of $\boldsymbol{V}$. radiata $L$ [Figure 4]}

Table 2 summarizes the effect of chromium-contaminated soil on total chlorophyll content of $V$. radiata $L$. After the $15^{\text {th }}$ day of

Table 2: Observation on the $15^{\text {th }}$ day of germination

\begin{tabular}{|c|c|c|c|c|c|c|}
\hline Pot & $\begin{array}{c}\text { Shoot } \\
\text { length }(\mathrm{cm})\end{array}$ & $\begin{array}{c}\text { Root } \\
\text { length }(\mathrm{cm})\end{array}$ & $\begin{array}{c}\text { Fresh } \\
\text { weight }(\mathrm{g})\end{array}$ & $\begin{array}{l}\text { Total chlorophyll } \\
\text { (mg/g fresh weight) }\end{array}$ & $\operatorname{Starch}(\mathrm{mg} / \mathrm{dl})$ & $\begin{array}{c}\text { Protein } \\
(\mathrm{mg} / 100 \mathrm{~g} \text { fresh weight })\end{array}$ \\
\hline Control soil & 12.1 & 4.5 & 0.62 & 0.504 & 150 & 29.789 \\
\hline $25 \%$ waste soil & 11.6 & 4.4 & 0.60 & 0.553 & 148 & 29.022 \\
\hline $50 \%$ waste soil & 8.9 & 3.5 & 0.55 & 0.460 & 135 & 23.628 \\
\hline $100 \%$ waste soil & 8.1 & 3.2 & 0.40 & 0.357 & 115 & 18.070 \\
\hline
\end{tabular}

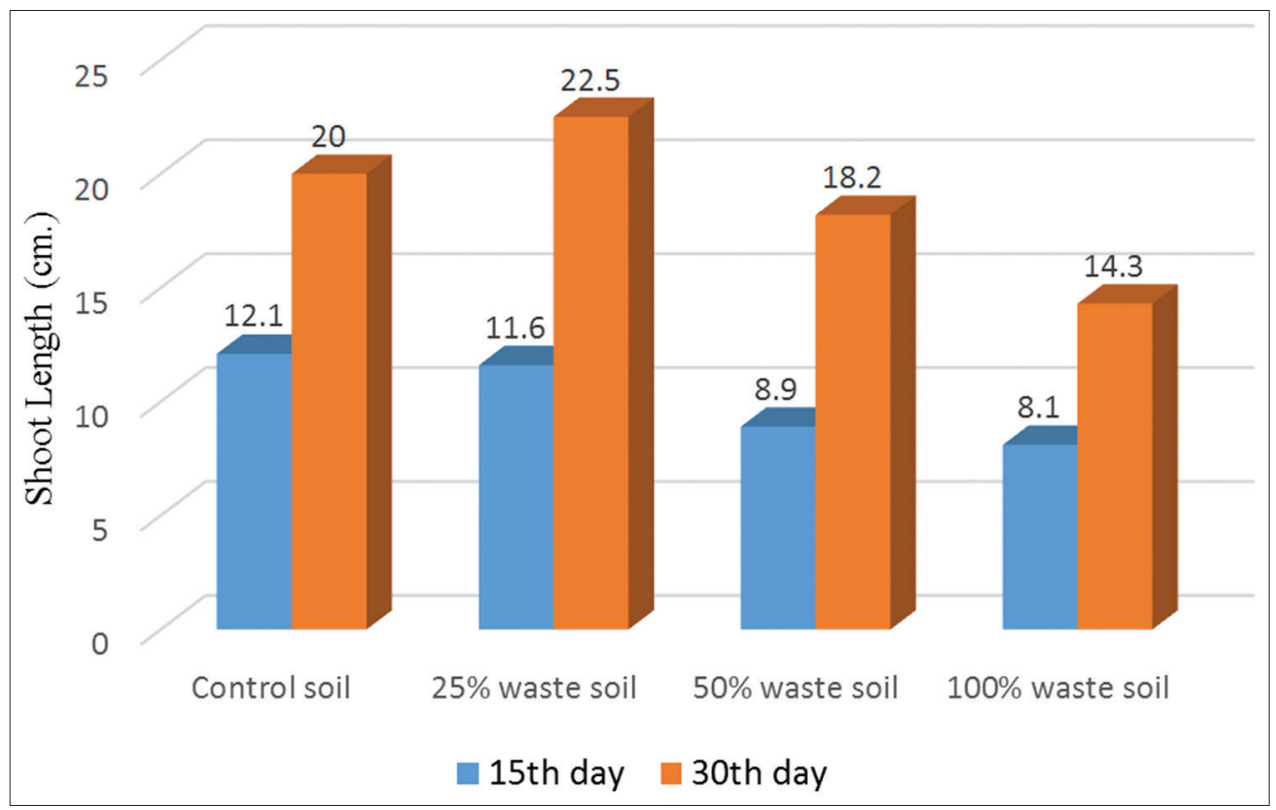

Figure 1: Comparative shoot length of Vigna radiata $L$ 
Table 3: Observation on the $30^{\text {th }}$ day of germination

\begin{tabular}{|c|c|c|c|c|c|c|}
\hline Pot & $\begin{array}{c}\text { Shoot } \\
\text { length }(\mathrm{cm})\end{array}$ & $\begin{array}{c}\text { Root } \\
\text { length }(\mathrm{cm})\end{array}$ & $\begin{array}{c}\text { Fresh } \\
\text { weight }(\mathrm{g})\end{array}$ & $\begin{array}{l}\text { Total chlorophyll } \\
\text { (mg/g fresh weight) }\end{array}$ & Starch (mg/dl) & $\begin{array}{c}\text { Protein } \\
\text { (mg/100 } \mathrm{g} \text { fresh weight) }\end{array}$ \\
\hline Control soil & 20.0 & 7.2 & 2.21 & 0.579 & 227 & 51.06 \\
\hline $25 \%$ waste soil & 22.5 & 7.9 & 2.39 & 0.629 & 236 & 65.90 \\
\hline $50 \%$ waste soil & 18.2 & 6.3 & 2.09 & 0.500 & 215 & 38.57 \\
\hline $100 \%$ waste soil & 14.3 & 5.2 & 1.97 & 0.397 & 153 & 33.07 \\
\hline
\end{tabular}

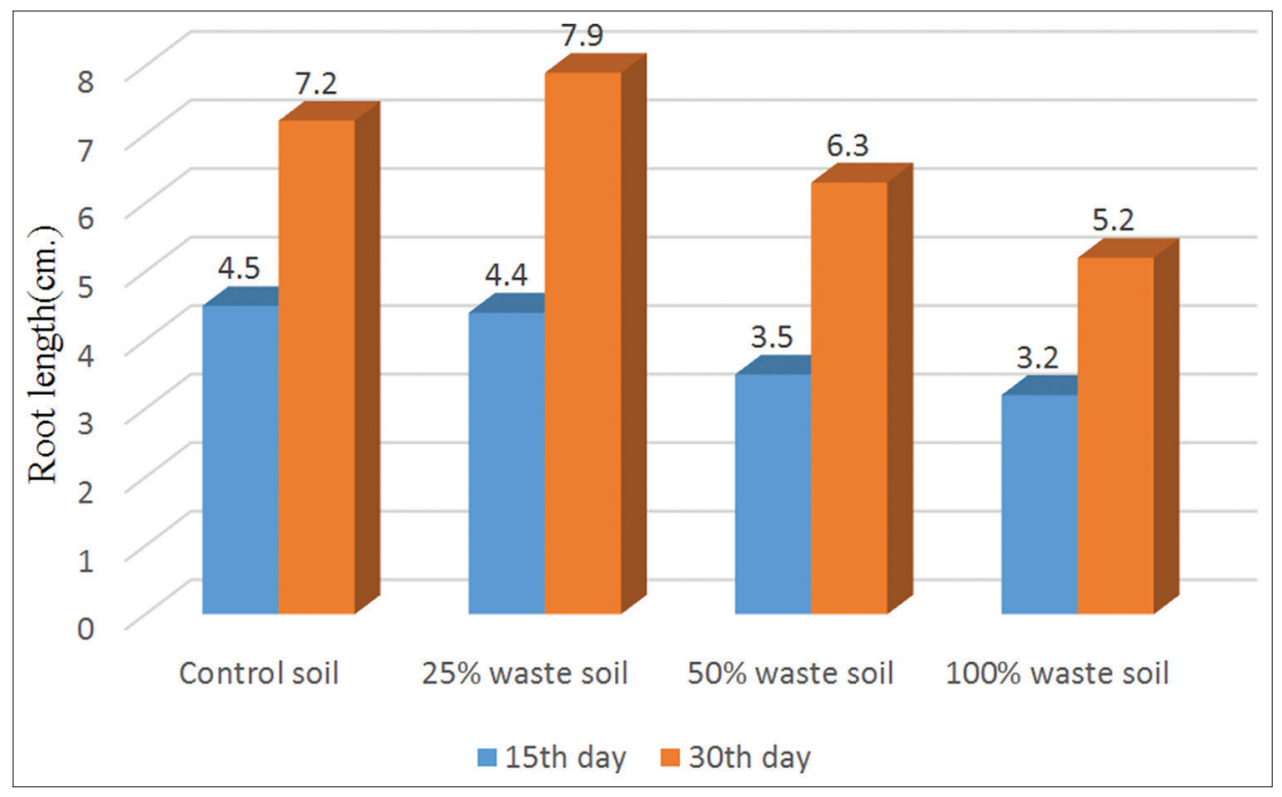

Figure 2: Comparative root length of Vigna radiata $\mathrm{L}$

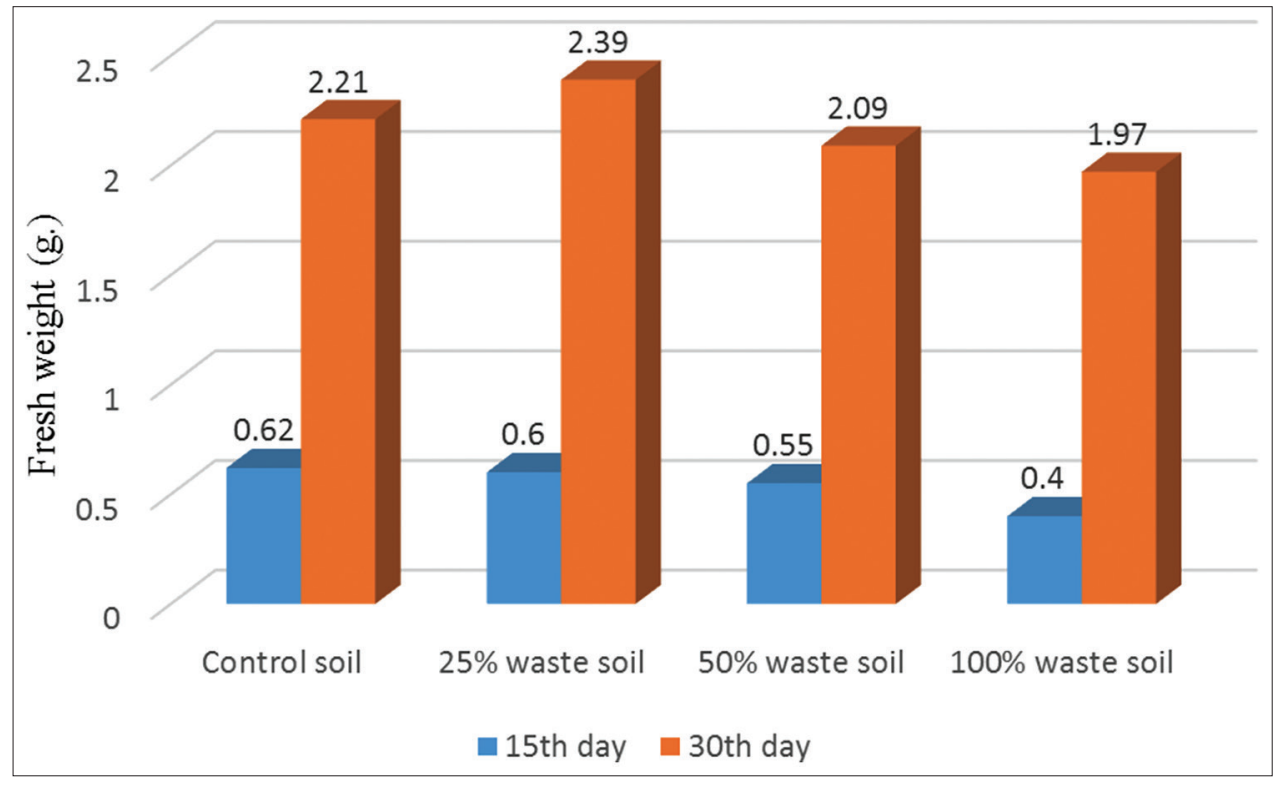

Figure 3: Comparative fresh weight of Vigna radiata L

germination, the table showed that the concentration of chlorophyll was found highest in $25 \%$ contaminated soil and followed by control, $50 \%$ contaminated soil. The concentration was lowest in $100 \%$ contaminated soil. After the $30^{\text {th }}$ day of germination [Table 3], the chlorophyll content was also recorded highest in $25 \%$ contaminated soil, followed by control, the $50 \%$ contaminated soil. The lowest was also recorded in $100 \%$ contaminated soil after the $30^{\text {th }}$ day of germination.

Reduced chlorophyll content of crops may be due to the interaction of enzymes involved in chlorophyll biosynthetic pathways in most plants under chromium stress [26]. 


\subsection{Effect of Chromium-contaminated Soil on Starch Content of V. radiata L [Figure 5]}

Table 2 summarizes the effect of chromium-contaminated soil on starch content of $V$. radiata $\mathrm{L}$. After the $15^{\text {th }}$ day of germination, the table showed that the concentration of starch was found highest in control and followed by $25 \%$ and $50 \%$ contaminated soil. The concentration was lowest in $100 \%$ contaminated soil.

After the $30^{\text {th }}$ day of germination [Table 3], the concentration of starch was found to be highest in $25 \%$ contaminated soil and followed by control, $50 \%$ contaminated soil. The concentration was lowest in $100 \%$ contaminated soil.

Reduced germination percentage of plants at higher chromium concentrations may be attributed to the interference of metal ions which may obstruct seed germinations by exerting unfavorable effect in the utilization of major seed reservoirs like starch [27].

\subsection{Effect of Chromium-contaminated Soil on Protein Content of $V$. radiata $L$ [Figure 6]}

Table 2 summarizes the effect of chromium-contaminated soil on protein content of $V$. radiata $L$. After the $15^{\text {th }}$ day of germination, the table showed that the concentration of protein was found highest in control and followed by $25 \%$ and $50 \%$ contaminated soil. The concentration was lowest in $100 \%$ contaminated soil.

After the $30^{\text {th }}$ day of germination [Table 3], the concentration of protein was found to be highest in $25 \%$ contaminated soil and followed by control, $50 \%$ contaminated soil. The concentration was lowest in $100 \%$ contaminated soil. Chromium reduces soluble protein in agricultural crops [28].

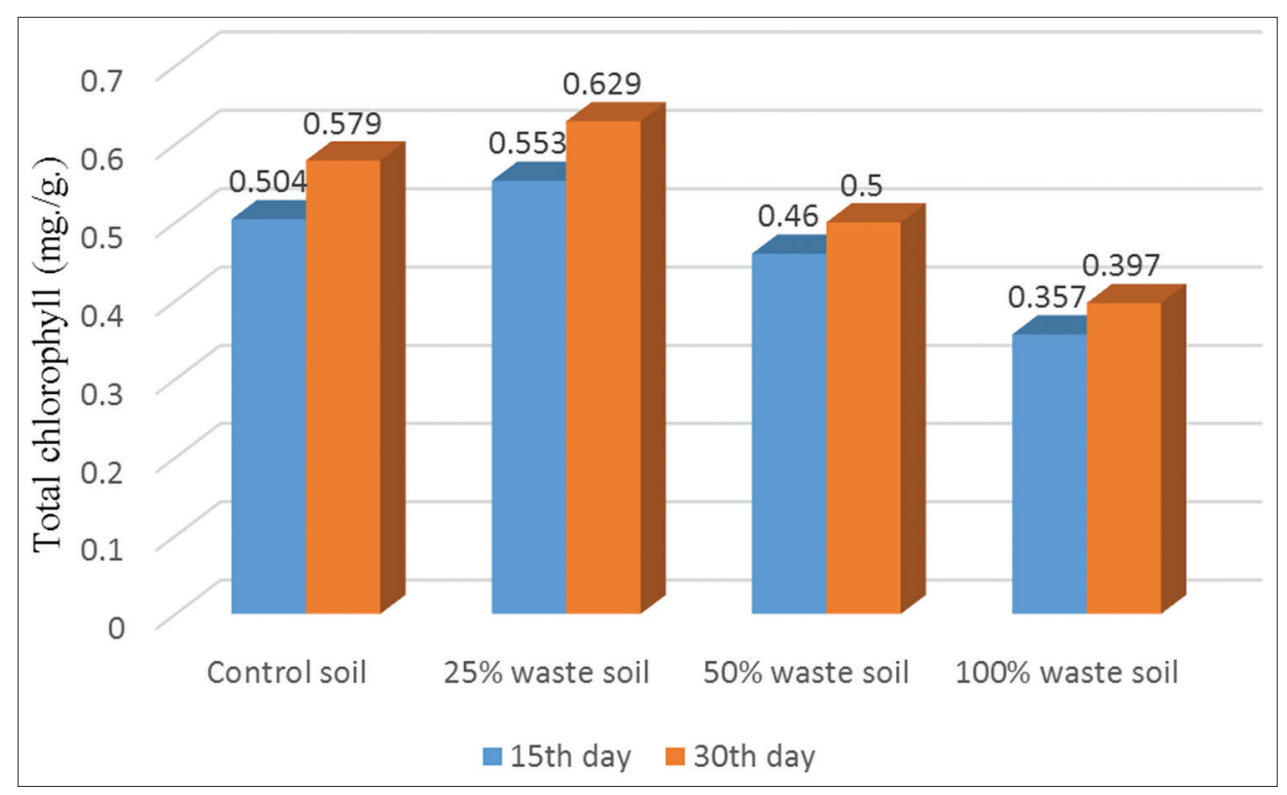

Figure 4: Comparative total chlorophyll content in leaves of Vigna radiata $\mathrm{L}$

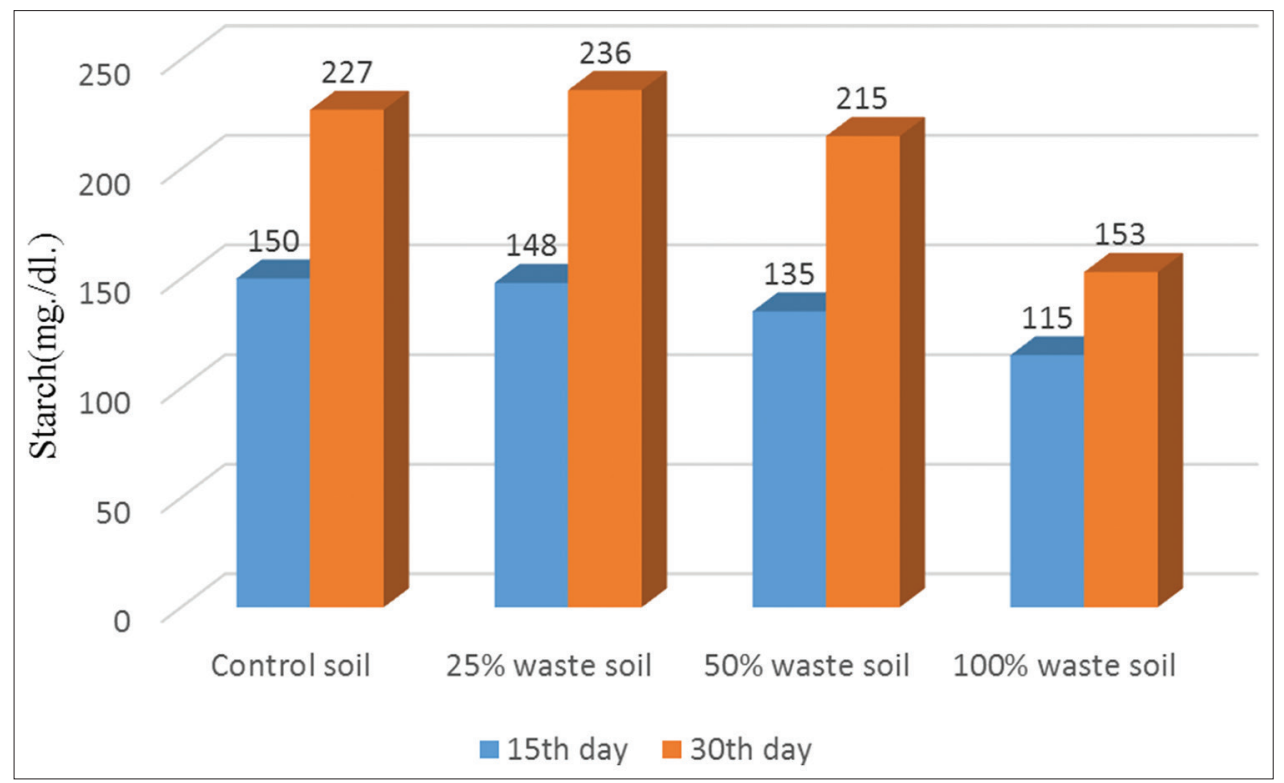

Figure 5: Comparative starch content in leaves of Vigna radiata $\mathrm{L}$ 


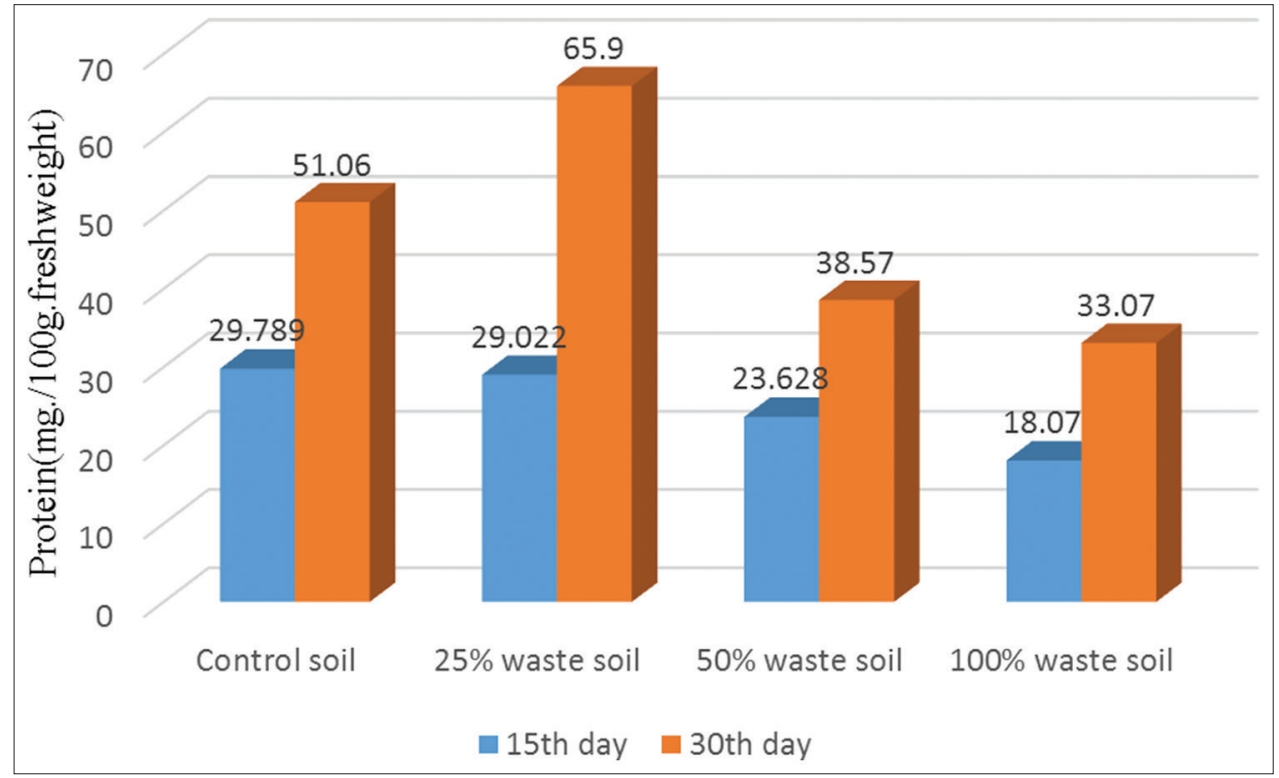

Figure 6: Comparative protein content in leaves of Vigna radiata L

\section{CONCLUSION}

From the above discussion, it is concluded that harmful effects on physiological and biochemical parameters of $V$. radiata $\mathrm{L}$. are increasing with increasing chromium toxicity. However, the parameters are normal in control soil. Hence, the heavy metal contamination should be limited to get better response. Remediation techniques such as excavation, stabilization of metals in soil, and use of growing plants from increasing contamination or to evacuate metals by phytoremediation should be implemented to get heavy metal contamination under control.

\section{REFERENCES}

1. Cseh E. Metal permeability, transport and efflux in plants. In: Prasad MN, Strzalka K, editors. Physiology and Biochemistry of Metal Toxicity and Tolerance in Plants. Dordrecht, NL: Kluwer Academic Publishers; 2002. p. 1-36.

2. Pilon-Smits E. Phytoremediation. Annu Rev Plant Biol 2005;56:15-39.

3. Grant CA, Buckley WT, Bailey LD, Selles F. Cadmium accumulation in crops. Can J Plant Sci 1998;78:1-17.

4. Jindal R, Kaur B. Effect of heavy metal toxicity on the productivity of a fresh water ecosystem. Indian J Ecol 2000;27:27-32.

5. Hall JL. Cellular mechanisms for heavy metal detoxification and tolerance. J Exp Bot 2002;53:1.

6. Axtell NR, Sternberg SP, Claussen K. Lead and nickel removal using microspora and lemna minor. Bioresour Technol 2003;89:41-8.

7. Cobbett CS. Heavy metals and plants-model systems and hyper accumulators. New Phytol 2003;159:289-93.

8. Stolt P, Asp H, Hultin S. Genetic variation in wheat cadmium accumulation on soils with different cadmium concentrations. J Agron Crop Sci 2006;192:201-8.

9. Panda SK. Heavy metal phytotoxicity induces oxidative stress in Taxithelium sp. Curr Sci 2003;84:631-3.

10. Bassi M, Corradi MG, Realini M. Effects of chromium (VI) on two freshwater plants, Lemna minor and Pistiastratiotes. Morphol Observ Cytobios 1990;62:27-38.

11. Panda SK, Choudhury S. Changes in nitrate reductase (NR) activity and oxidative stress in moss Polytrichum commune subjected to chromium, copper and zinc toxicity. Braz J Plant Physiol 2004;17:191-7.

12. Teisseire H, Guy V. Copper-induced changes in antioxidant enzymes activities in fronds of duckweed (Lemna minor). Plant Sci 2000;153:65-72.

13. Bal W, Kasprzak KS. Induction of oxidative DNA damage by carcinogenic metals. Toxicol Lett 2002;127:55-62.

14. Apel K, Hirt H. Reactive oxygen species: Metabolism, oxidative stress, and signal transduction. Annu Rev Plant Biol 2004;55:373-99.

15. Noctor G, Foyer $\mathrm{CH}$. Ascorbate and glutathione: Keeping active oxygen under control, annual review plant physiology. Plant Mol Biol 1998;49:249-79.

16. Zhang Y, Qi H, Taylor R, Xu W, Liu LF, Jin S, et al. The role of autophagy in mitochondria maintenance: Characterization of mitochondrial functions in autophagy-deficient S. Cerevisiae strains. Autophagy 2007;3:337-46.

17. Siedlecka A, Krupa Z. Functions of enzymes in heavy metal treated plants. In: Prasad MN, Kazimierz S, editors. Physiology and Biochemistry of Metal Toxicity and Tolerance in Plants. The Netherlands: Kluwer; 2002. p. 314-7.

18. Poschenrieder C, Vazquez MD, Bonet A, Barcelo J. Chromium III iron interaction in iron sufficient and iron deficient bean plants. II Ultrastructural aspects. J Plant Nutr 1991;14:415-28.

19. Panda SK, Parta HK. Does Cr (III) produces oxidative damage in excised wheat leaves. J Plant Biol 2000;27:105-10.

20. Han FX, Sridhar BB, Monts DL, Su Y. Phytoavailability and toxicity of trivalent and hexavalent chromium to Brassica juncea. New Phytol 2004;162:489-99.

21. Subbiah BV, Asija AS. A rapid procedure for the estimation of available Nitrogen in soil. Curr Sci 1956;25:259-60.

22. Arnon D. Copper enzymes isolated chloroplasts, polyphenol oxidase in Beta vulgaris. Plant Physiol 1949;24:1-15.

23. Lowry OH, Rosebrough NJ, Farr AL, Randall RJ. Protein measurement with the folin phenol reagent. J Biol Chem 1951;193:265-75.

24. Clegg KM. The application of the anthrone reagent to the estimation of starch in cereals. J Sci Food Agric 1956;7:40-4.

25. Sharma DC, Chatterjee C, Sharma CP. Chromium accumulation by Barley seedlings (Hordeum vulgare L.). J Exp Bot 1995;25:241-51.

26. Shanker K, Cervantes C, Loza-Tavera H, Avudainayagam S. Chromium toxicity in plants. Environ Int 2005;31:739-53. 
27. Dua A, Sawhney SK. Effect of chromium on activities of hydrolytic enzymes in germinating pea seeds. Environ Exp Bot 1991;31:133-9.

28. Hemalatha S, Anburaj A, Francis K. Effect of heavy metals on certain biochemical constituents and nitrate reductase activity in Oryza sativa L. Seedlings. J Environ Biol 1997;18:313-9.
How to cite this article:

Rath BP, Hota S, Subhadarshini S, Dash D, Das PK. Consequence of chromium-tainted soil on physical and biochemical responses of Vigna radiata L. J App Biol Biotech. 2019;7(01):35-41.

DOI: 10.7324/JABB.2019.70107 